\title{
Market Level Price Analysis of Copra Trading in the Philippines
}

\author{
Susan M. Rivera, Ph.D ${ }^{1}$ and Flordeliza A. Lantican, Ph.D ${ }^{2}$
}

\begin{abstract}
The dynamics in market level prices was examined for Philippine copra trading. The analysis of the price formation process in the copra miller-dealer-farmer markets showed that a weak form of market integration characterized the trading of copra resecada between dealers and millers in all Philippine regions. In contrast, integration of any form was absent between miller-farmer and dealerfarmer in all regions except in Region V. Likewise, no integration was noted in all market levels when dealers and millers used copra resecada price while farmers were given the copra corriente Pasa price. Important factors were identified that contributed to the level of market integration. Recommendations made encompass areas on coconut production and productivity, market infrastructure and facilities, and pricing system in copra trading.
\end{abstract}

Keywords: market integration, market level price analysis, copra market system, copra quality, Ravallion model.

1 Senior Science Research Specialist, Philippine Coconut Authority, Zamboanga Research Center, 7000, San Ramon, Zamboanga City, Philippines. Email: smrzambo@yahoo.com

2 Professor, Department of Agricultural Economics, University of the Philippines at Los Baños, College, Laguna, Philippines. Email: flantican@yahoo.com 


\section{Introduction}

The coconut industry in the Philippines encompasses about 3.5 million families directly working in the coconut farm sector and about 25 million Filipinos indirectly dependent on the industry such as traders, exporters, and processors. Its importance is further reflected in the value of its economic contribution. Next to rice industry, it has the second largest contribution to Gross Value Added (GVA). In view of its immense importance, the Philippine government had issued policies and legislations for the past three decades to improve the coconut industry.

Within a span of four decades since the 1940s, the industry evolved into a competitive agri-based commodities trading system supported by millions of coconut farmers selling in small lots to dealers for final delivery to millers. In view of how the industry evolved over time and the variation of factors affecting prices, there is a need to study how well copra at different market levels is integrated. The copra marketing system is price efficient if price changes are fully transmitted between market levels that prohibit private traders from obtaining abnormal profits. This is possible only in markets that are well integrated.

\section{Methodology}

The study covered ten (10) regions in the Philippines namely: Regions IVA, V, and NCR in Luzon; Regions VI, VII, and VIII in Visayas; and Regions IX, X, XI, and XII in Mindanao. The primary data were collected through a survey of coconut farmers, dealers, and millers. The market level copra price relationships was tested using farm gate price, dealer price, and miller price within each region for the same period. Time series data for copra following the old classification (copra resecada and copra corriente) was used. These data were gathered from the Philippine Coconut Authority (PCA) and Bureau of Agricultural Statistics (BAS).

The stationarity of each variable was tested using Dickey-Fuller (DF) or Augmented DickeyFuller (ADF) tests (Sinharoy and Nair, 1994). The Ravallion model (Faminow and Benson,
1990) was used to test the dynamics in market level price relationships.

Analysis of factors at the different market levels in relation to market integration data involved regression and correlation analyses.

\section{Results and discussions}

\section{The copra product}

Copra is a homogenous product with differentiation in terms of quality as indicated by its moisture content (MC). The old classification of copra followed the standards and grades as set by PCA and industry members. Copra resecada was set as those with 6-13\% MC while copra corriente are those with higher MC (>14\%). The new copra classification standards of 1991 maintained the base price of copra at $12 \%$ moisture (semiresecada) but in addition reduced the rejection level to $12 \%$. In effect this means that the "pasa" system (a system where there was an automatic deduction on copra having $14 \%$ or higher MC judged only by its appearance) of trading will cease. Tapahan dried copra was permitted to be traded within the moisture range of $12.1-14 \%$ provided that this copra was dried down immediately to at least $12 \%$ by traders with drying facilities. A table with price adjustment factor to allow for weight loss during the drying from $12 \%$ to $7 \%$ moisture served as basis for relating MC to price.

On the other hand, to further promote the quality and marketability of coconut oil and copra that is consistent with prevailing market prices, the 2003 revision of the price adjustment scale for MC in copra stated that the "on-thespot" price of copra at the mill or farm gate shall apply to the weight of copra adjusted with a deduction calculated from the difference between prescribed and actual MC. No deduction shall apply to trade copra resecada/bodega with $6 \% \mathrm{MC}$ but prescribed deductions apply within the MC range of 6.1$13.9 \%$. Copra with $14 \% \mathrm{MC}$ and above was deemed non-merchantable for export or processing to other by-products. In June 2004, a new copra classification table was put in place after months of an information campaign to 
address the issues of high aflatoxin in copra meal and high free fatty acid content of the oil. The order aimed to prohibit the trading of high moisture copra and penalize prolonged storage that resulted in very low moisture copra.

\section{Price Differential of Market Level Prices Within Regions}

Copra resecada. On the average, the miller copra price was less than the dealer price by $\mathrm{PhP}$ $0.03 / \mathrm{kg}$ (Table 1). Region VIII had higher mill gate price than dealer price because the oil mills in the region were more cost efficient due to their proximity to the supply source and due to their application of cost reducing measures in partnership with oil mills in other regions. For Region VII, price differential was a low positive (P 0.001). This situation could be attributed to the practice of many big dealers based in Region VII who offered a competitively higher price to attract Region VIII dealers. The strategy includes price speculating, setting target volume, price negotiating based on volume, and calling on fellow dealers with an offer. Hence, although the Region VII mill gate price was lower than the dealer price, the negotiated price can go higher when the dealer has the volume. As the millers said, "traders trade while millers accommodate". Another factor which may have also contributed to the lower mill gate copra price than the dealer price in Region VII was the less aggressive stance of millers to compete for copra supply in the presence of palm oil supply. Accordingly, the volume of copra procurement of certain millers in Region VII decreased in 2004 because of the low price of imported palm oil, which was highly demanded by industrial and fast food chain clients.

The price differential between buying stations and dealers followed a similar trend. Except for Region IVA in Luzon, which posted a positive price differential in its mill gate price to attract dealers from other regions, buying stations had lower prices than dealers by $\mathrm{PhP} 0.24 / \mathrm{kg}$ on the average. The price difference in Visayas was mainly due to inter-regional freight cost to their oil mill and the administrative cost of operating buying stations. On the other hand, a positive price differential was observed at the millerfarm $(\mathrm{PhP} 1.50 / \mathrm{kg})$ and dealer-farm level $(\mathrm{PhP1.19} / \mathrm{kg})$.

Table 1. Price differential of copra resecada by market levels, Philippines, 19912003

\begin{tabular}{|c|c|c|}
\hline $\begin{array}{c}\text { MARKET } \\
\text { LEVEL }\end{array}$ & REGION & $\begin{array}{c}\text { PRICE } \\
\text { DIFFERENTIAL } \\
(\mathrm{PhP} / \mathrm{kg})\end{array}$ \\
\hline \multirow{6}{*}{$\begin{array}{l}\text { Miller - } \\
\text { Dealer }\end{array}$} & $\mathrm{V}$ & -0.10 \\
\hline & VII & 0.00 \\
\hline & VIII & 0.12 \\
\hline & IX & -0.11 \\
\hline & XI & -0.07 \\
\hline & Average & -0.03 \\
\hline \multirow{4}{*}{$\begin{array}{l}\text { Buying } \\
\text { station - } \\
\text { Dealer }\end{array}$} & Luzon & 0.96 \\
\hline & Visayas & -0.85 \\
\hline & Mindanao & -0.43 \\
\hline & Average & -0.24 \\
\hline \multirow{6}{*}{$\begin{array}{l}\text { Miller - } \\
\text { Farm gate }\end{array}$} & IVA & 2.23 \\
\hline & V & 0.42 \\
\hline & VIII & 2.87 \\
\hline & $X$ & 0.96 \\
\hline & XI & 0.50 \\
\hline & Average & 1.50 \\
\hline \multirow{4}{*}{$\begin{array}{l}\text { Dealer - } \\
\text { Farm gate }\end{array}$} & $\bar{V}$ & 0.52 \\
\hline & VIII & 2.81 \\
\hline & XI & 0.63 \\
\hline & Average & 1.19 \\
\hline
\end{tabular}

Overall, the farm-dealer-mill average copra resecada price of five regions showed that miller-dealer price difference $(\mathrm{PhP}-0.03 / \mathrm{kg}$ ) was much lower than the miller-farm $(\mathrm{PhP} 1.50 / \mathrm{kg})$ or dealer-farm $(\mathrm{PhP} 1.19 / \mathrm{kg})$ price difference.

Copra resecada - copra corriente. In the selected regions covered, farm copra resecada price was higher than farm copra corriente price

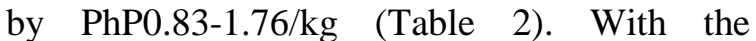
difference in copra quality, average price differential at the mill-farm was $\mathrm{PhP} 2.38 / \mathrm{kg}$. Luzon and Visayas regions ( $\mathrm{PhP} 2.18-3.62 / \mathrm{kg})$ 
had a higher mill-farm price differential than Mindanao regions (PhP1.42-2.00/kg). At the dealer-farm level, the average price differential was PhP2.40/kg with Luzon and Visayas regions $(\mathrm{PhP} 2.29 / \mathrm{kg}-\mathrm{PhP} 3.20 / \mathrm{kg})$ having larger price differentials than the Mindanao regions (PhP1.55/kg-PhP2.05/kg).

Table 2. Price differential of copra resecadacopra corriente by market levels, Philippines, 1991-2003

\begin{tabular}{|c|c|c|}
\hline $\begin{array}{l}\text { MARKET } \\
\text { LEVEL }\end{array}$ & REGION & $\begin{array}{c}\text { PRICE } \\
\text { DIFFERENTIAL } \\
\text { (RESECADA- } \\
\text { CORRIENTE) } \\
(\mathrm{PhP} / \mathrm{kg})\end{array}$ \\
\hline \multirow{6}{*}{$\begin{array}{l}\text { Farmer } \\
\text { (Farm } \\
\text { gate) }\end{array}$} & IVA & 1.39 \\
\hline & $\mathrm{V}$ & 1.76 \\
\hline & VIII & 0.85 \\
\hline & $\mathrm{X}$ & 0.83 \\
\hline & XI & 0.92 \\
\hline & Average & 0.85 \\
\hline \multirow{10}{*}{$\begin{array}{l}\text { Miller - } \\
\text { Farm gate }\end{array}$} & \multirow[t]{2}{*}{ Luzon } & 3.62 \\
\hline & & 2.18 \\
\hline & \multirow[t]{2}{*}{ Visayas } & 2.56 \\
\hline & & 2.93 \\
\hline & VIII & 3.31 \\
\hline & Mindanao IX & 2.00 \\
\hline & $X$ & 1.79 \\
\hline & $\mathrm{XI}$ & 1.42 \\
\hline & XII & 1.58 \\
\hline & Average & 2.38 \\
\hline \multirow{6}{*}{$\begin{array}{l}\text { Dealer - } \\
\text { Farm gate }\end{array}$} & $\mathrm{V}$ & 2.29 \\
\hline & VII & 2.93 \\
\hline & VIII & 3.20 \\
\hline & IX & 2.05 \\
\hline & XI & 1.55 \\
\hline & Average & 2.40 \\
\hline
\end{tabular}

\section{Dynamics in Market Level Prices}

Trading of copra resecada between dealers and millers in all regions was characterized by a weak and long run integration (Figure 1 and Table 3). There was a less than perfect basingpoint system in place, where the dealer bases the price offered on the price set by the miller in all the regions. Overall, price formation between the dealers and millers was more connected than the price realization between the farmers and dealers/millers. In an oligopolistic setting, however, this has other implications on the efficiency of price transmission.

Figure 1. Market integration relationship copra resecada by market level, Philippines, 1991-2003

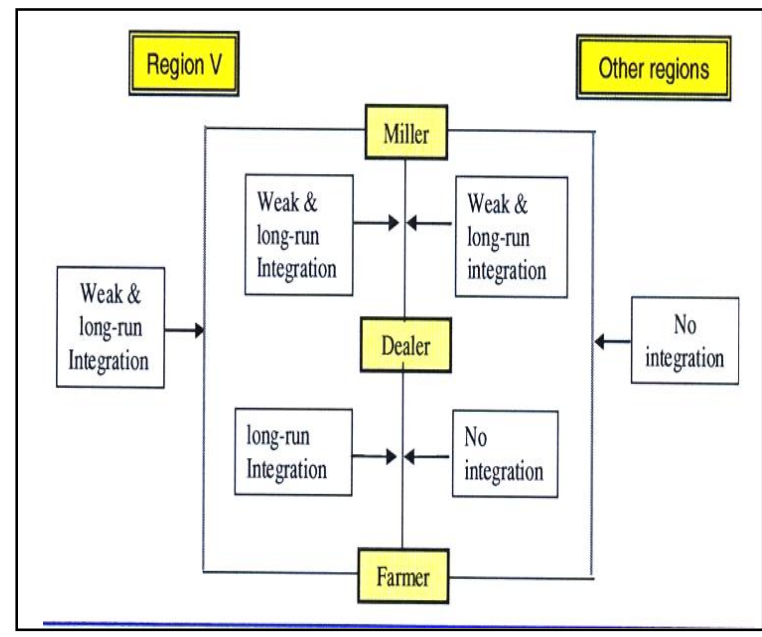

The price formation relationship of the farmer-miller in Region V was characterized by a less than perfect basing point system where the farmer based on the miller. This implies that the miller leads the price realization process. Further, the price system between the farmer and the dealer can be described as competitive FOB pricing since the weak form of integration was rejected but the long run form was accepted. In essence, Region $\mathrm{V}$ is a major coconut producing region but its copra production is only about $26 \%$ of the total milling capacity of the five oil mills in the region. Therefore, aggressive copra procurement by millers may be imminent. One of the events which may have a bearing to the result of a basing-point pricing system between the farmers and miller in Region $\mathrm{V}$ was the role of the broker and big traders in the "toll crushing agreement" (TCA) in the area. On the other hand, there was no integration observed at all levels when dealers and millers used copra resecada price while farmers were given the copra corriente or Pasa price (Fig 2). 
Figure 2. Market integration relationships by market level using different copra quality (copra corriente-copra resecada), Philippines, 1991-2003

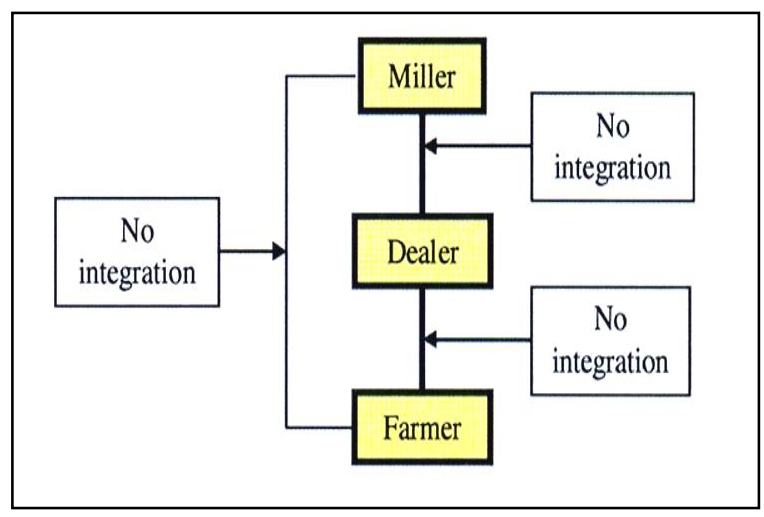

\section{Factors Affecting Integration and efficiency at the Market Level}

Self-sufficiency in production. There was no integration observed at the miller-farmer and dealer-farmer levels. This could be partly attributed to the low production at the farm level. It was noted that most farmers surveyed had a low volume of nuts harvested (i.e., 35\% of the recorded harvests were below 3,000 nuts). And since farmers had limited sources of income, they often harvest and sell immediately regardless of the level of the current price. Results showed that market integration can be enhanced with increased trade flow and improved coconut production. Farmers were able to avail of a better price with higher volume of nuts harvested and copra sold (Table 4).

Improved coconut production was significantly correlated with the type of coconut variety planted and age of palm. The hybrids showed high potential even at a young average age of eight years.

Difference in copra quality. Variation in product quality, be it a result of a pricing system using the Pasa approach or a real inferiority in quality of copra traded, had a highly significant effect on the failure of market integration at the different market levels. As such, the farm-dealer and farm-miller copra marketing levels were grossly price-inefficient. Prices at the miller and dealer levels were not efficiently transmitted to the farm level. These results imply that policies geared towards improving mill copra prices cannot raise the farm income while the pricing system or Pasa system is still being practiced.

About $43 \%$ of the farmers surveyed perceived that the quality of copra affected copra price at the farm level. The correlation analysis also revealed that the use of a MC meter at the point of sale was significantly associated with a higher price. An average copra sale with the use of the moisture meter device recorded a higher price (PhP18.53/kg) compared to copra sale using the visual approach (PhP17.21/kg). However, data showed that $82 \%$ of the copra sales for the period were made using the visual approach (Table 5).

The reasons why the visual approach is dominant given by farmers were (1) the traders did not have a MC meter; (2) the traders had a moisture meter but do not use them; (3) the farmers did not want to wait for the result of the MC reading and opted for immediate cash payments; (4) the Pasa system was the traditional way and moisture reading is not practiced in the area; (5) the volume of copra to be sold was low so there was no need for a moisture reading; (6) the buyers were just small traders; and (7) the buyers did not care.

Using the visual method approach in buying copra, the Pasa system with the automatic deductions of $14 \%$ on the copra volume being sold by the farmer prevailed even if the copra was resecada. Moreover, if the copra was presumed inferior in quality by the buyers, further deductions were imposed. About $86 \%$ of the copra sales for the period covered were given $14 \%$ to $22 \%$ deductions.

Although millers and traders used the MC meter when trading with each other, they did not generally use this when dealing with farmers. About $81.5 \%$ of the traders still used the visual approach in buying copra from farmers and only $18.5 \%$ of them used the moisture meter when buying copra from other traders. About $70 \%$ of the traders reported that the moisture contents of copra from farmer-sellers were greater than $14 \%$ using the visual approach. Moreover, about $14 \%$ of these traders recorded $6.1-12 \% \mathrm{MC}$ for 
Table 3. F-statistic for pricing behavior tests by market level (copra resecada), Philippines, 1991-2003

\begin{tabular}{|c|c|c|c|c|}
\hline \multirow[b]{2}{*}{ REGION } & \multirow[b]{2}{*}{ INDEPENDENCE $^{1}$} & \multicolumn{2}{|c|}{ SHORT RUN INTEGRATION } & \multirow{2}{*}{$\begin{array}{c}\text { LONG RUN } \\
\text { INTEGRATION }^{4}\end{array}$} \\
\hline & & $\begin{array}{l}\text { STRONG } \\
\text { FORM }^{2}\end{array}$ & $\begin{array}{r}\text { WEAK } \\
\text { FORM }^{3}\end{array}$ & \\
\hline \multicolumn{5}{|l|}{ Dealer-Miller } \\
\hline $\mathrm{V}$ & $678.20 * *$ & $14.48 * *$ & 0.79 & 1.38 \\
\hline VII & $895.60 * *$ & $23.42 * *$ & 0.07 & 0.06 \\
\hline VIII & $483.90^{* *}$ & $8.79 * *$ & 0.92 & 1.29 \\
\hline IX & $769.20 * *$ & $11.59 * *$ & 0.68 & -0.004 \\
\hline XI & $787.90 * *$ & $12.69 * *$ & 1.26 & 0.66 \\
\hline \multicolumn{5}{|l|}{ Farmer-Miller } \\
\hline IVA & $13.90 * *$ & $16.51 * *$ & $20.61 * *$ & $27.43 * *$ \\
\hline $\mathrm{V}$ & $160.70^{* *}$ & $11.13^{* *}$ & 1.85 & 3.11 \\
\hline VI & $14.90 * *$ & $66.71 * *$ & $99.23^{* *}$ & $53.85 * *$ \\
\hline VIII & $58.60 * *$ & $9.56 * *$ & $9.67 * *$ & $10.62 * *$ \\
\hline$X$ & $123.60 * *$ & $20.43 * *$ & $7.4 * *$ & $4.22 *$ \\
\hline XI & $130.50 * *$ & $15.36 * *$ & $10.47 * *$ & $20.93 * *$ \\
\hline XII & $138.40 * *$ & $26.59 * *$ & $15.32 * *$ & $15.74 * *$ \\
\hline \multicolumn{5}{|l|}{ Farmer-Dealer } \\
\hline V & $138.40^{* *}$ & $16.64 * *$ & $5.31 * *$ & 3.06 \\
\hline VIII & $57.00 * *$ & $13.92 * *$ & $15.35 * *$ & $10.85 * *$ \\
\hline XI & $108.50 * *$ & $21.59 * *$ & $10.07 * *$ & $19.79 * *$ \\
\hline
\end{tabular}

** and * Significant at $1 \%$ and $5 \%$ probability level, respectively

${ }^{1}$ Contemporaneous and lagged effects at one location are independent of prices at another location

${ }^{2}$ Basing point pricing (price adjustments are fully reflected in the same time period with no lagged effects)

${ }^{3}$ Less than perfect basing point system (the lagged effects vanish on average)

${ }^{4}$ Price reactions are equal to one. Competitive FOB oligopoly exists when the short run tests are rejected and the long run test accepted

Table 4. Copra price paid to farmers based on the volume of nuts harvest and on amount of copra, Philippines, 2005

\begin{tabular}{|ccc|c|}
\hline COPRA SOLD & & PRICE \\
\hline $\mathrm{Kg}$ & No. & $\%$ & $\mathrm{PhP} / \mathrm{kg}$ \\
\hline$\leq 999$ & 214 & 53.5 & $17.06 \mathrm{c}$ \\
$1000-1999$ & 125 & 31.2 & $17.86 \mathrm{bc}$ \\
$2000-2999$ & 29 & 7.2 & $17.67 \mathrm{bc}$ \\
$3000-3999$ & 15 & 3.8 & $17.35 \mathrm{bc}$ \\
$4000-4999$ & 10 & 2.5 & $18.57 \mathrm{ab}$ \\
$\geq 5000$ & 7 & 1.8 & $19.47 \mathrm{a}$ \\
Total / Mean & 400 & 100 & 17.44 \\
Level of significance & & & $* *$ \\
CV (\%) & & 11.42 \\
\hline
\end{tabular}

${ }^{1}$ Means with the same letter are not significantly different.

** - significant at $1 \%$ probability level

Source: Survey of coconut farmers, Philippines, 2005 
Table 5. Copra price of farmers based on moisture content (MC) determination methods, Philippines, 2005

\begin{tabular}{|c|c|c|c|c|}
\hline \multirow{2}{*}{\multicolumn{2}{|c|}{ COPRA MOISTURE CONTENT (MC) }} & \multicolumn{2}{|c|}{ SALES } & \multirow[t]{2}{*}{$\mathrm{PCF}^{1}$} \\
\hline & & No. & $\%$ & \\
\hline \multirow{5}{*}{$\begin{array}{l}\text { MC determination } \\
\text { method }\end{array}$} & Visual & 328 & 82 & $17.21 \mathrm{~b}$ \\
\hline & Use meter & 72 & 18 & $18.53 \mathrm{a}$ \\
\hline & Total & 400 & 100 & 17.44 \\
\hline & \multirow{2}{*}{\multicolumn{2}{|c|}{$\begin{array}{l}\text { Level of significance } \\
\text { CV }(\%)\end{array}$}} & & $* *$ \\
\hline & & & & 11.33 \\
\hline \multirow{7}{*}{ Moisture content } & $\leq 6 \%$ & 5 & 1.2 & $21.42 \mathrm{a}$ \\
\hline & $6.1-10 \%$ & 12 & 3.0 & $19.82 \mathrm{~b}$ \\
\hline & $10.1-13.9 \%$ & 41 & 10.3 & $18.75 \mathrm{~b}$ \\
\hline & $14 \%-22 \%$ & 342 & 85.5 & $17.15 \mathrm{c}$ \\
\hline & Total & 400 & 100 & 17.44 \\
\hline & \multicolumn{3}{|c|}{ Level of significance } & $* *$ \\
\hline & \multicolumn{3}{|c|}{$\mathrm{CV}(\%)$} & 10.81 \\
\hline
\end{tabular}

${ }^{1}$ Means with the same letter are not significantly different.

** - significant at $1 \%$ probability level

Source: Survey of coconut farmers, Philippines, 2005

the copra sold by other traders. As such, about $15 \%$ of the traders reportedly gave discounts of $10.9-14 \%$ but majority of them $(60.5 \%)$ gave $14.1-25 \%$ discounts on copra sold by farmers.

At the miller-dealer level, copra traded usually underwent moisture content reading using the moisture meter. Hence, spot or contract prices with appropriate deductions were often ensured. About $90 \%$ of the traders used the moisture meter in selling, oftentimes to millers. The use of visual approach in copra trading (10\%) was observed when traders (i.e., municipal) sold to other traders (i.e. municipal/provincial/regional traders). Using the visual approach, the copra traded was all classified as resecada. About $62 \%$ of the discounts ranged from $0-7 \%$. At this level, the spot/contract price less discounts was appropriately implemented indicating that market integration was noted. Hence, with a uniform standard of copra quality traded as a result of an acceptable pricing practice, policies geared towards improving mill copra prices have a positive effect on increasing dealer's prices as well.

Long chain of intermediaries in the market structure. The correlation analysis of survey responses showed that the copra price that the farmers received was significantly associated with the type of buyer. The farmers surveyed usually sell to municipal and provincial traders. A positive association was noted between the copra price that the farmers received and the type of buyer based on their geographical coverage in buying and selling. Hence, higher farmers' copra price was associated with provincial/regional/interregional buyers. The relatively higher price could be attributed to the shorter marketing chain wherein fewer participants, who incorporate profit, were involved in the chain. Moreover, the type of buyer based on geographical coverage was also positively and significantly associated with the volume of copra sold. Hence, farmers with higher volume of copra to be traded often sold to bigger traders and negotiated for a higher copra price. Although on the average, the Pcf from the traders was lower than that from the millers ( $\mathrm{PhP} 17.35$ vs. PhP 18.39), about $94 \%$ of the farmers sold to traders and only about $6 \%$ sold directly to millers. This result could be attributed to the other marketing practices that closely linked the traders and the farmers. 
Farmers usually sell their copra to their regular buyers or "suki" (29\%), to buyers who offered them credit/marketing tie-up (24\%), and to buyers who offered higher copra price $(20 \%)$. The "suki" buyers were described as those who gave minimum deductions, had good relationship with the farmers, and normally offered cash advances. Credit/marketing tie-up took the form of Direct Copra Marketing (DCM) arrangements between the cooperative and the farmers; free transport cost for hauling, provision for cash advances with the condition that payments will be upon marketing of their copra; and more importantly, agreement that the copra are to be sold to the lender-buyers.

Related to this, copra price given to farmers was negatively associated with their credit status, the mode of payment for their copra, and source of capital or credit. Results of the survey showed that $60 \%$ of the farmers got credit from copra buyers and other sources. Meanwhile, the remaining $40 \%$ of the farmers had their own capital and did not resort to credit.

Results further showed the highly significant effect of the farmers' credit status on the copra price. Farmers without any credit received from buyers and/or from other sources were given significantly higher copra price compared to farmers who were provided with credit services by buyers (PhP17.84 vs. PhP17.18/kg copra). Likewise, farmers who used their own capital in copra production received a better price for their copra (PhP17.84/kg) compared to those who sourced their capital from their copra buyers (PhP17.26/kg). Moreover, farmers who sourced their capital from other sources got the least price for their copra (PhP16.12/kg).

Bottlenecks in transportation and infrastructure facilities. Gravel and dirt roads connected the farms of $70 \%$ of the farmers surveyed in selling copra. Notably, a higher freight cost of $\mathrm{PhP} 0.31 / \mathrm{kg}$ to $\mathrm{PhP} 0.34 / \mathrm{kg}$ was incurred by farmers for transporting via dirt and gravel roads, respectively, compared to a cost of

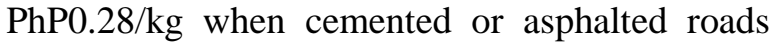
was used. Hence, the freight $\operatorname{cost} / \mathrm{kg} / \mathrm{km}$ was about $\mathrm{PhP} 0.12$ for dirt road and $\mathrm{PhP} 0.03$ for cemented/asphalted road. Farmers who had to traverse on dirt road and then transport copra by sea had much higher freight cost of PhP1.23/kg.

On the other hand, about $29 \%$ of the farmers surveyed relied on the transportation provided by the traders or they delivered and the buyer paid the freight cost. Related to this, the copra price of farmers was lower when they employed the pick-up method than when copra was delivered to buyers (PhP16.87/kg vs. $\mathrm{PhP} 17.72 / \mathrm{kg}$ ). About $63 \%$ of the copra sales were delivered to the buyers while $37 \%$ where picked up by the traders. Notably, most of the traders were equipped with trucks for copra procurement operations. Other modes of transportation reported by farmers were the use of public utility vehicles (29\%), hired/private vehicles (14\%), and horseback and animaldrawn (19\%).

Pricing practices. Current price determination and pricing practices at the farm level could hinder the farmers from getting the right price. At the farm level though, oligopolistic pricing proved to be disadvantageous to the farmers. The farmers tended to be just price takers and did not contribute in the price formation of the copra they sell. The farmers' survey responses denoted that the buying prices of copra at the farm level were based on the prevailing price (79\%). Accordingly, the prevailing price was usually set by millers and traders. About $89 \%$ of the farmers indicated that the buyers set the price while only $11 \%$ of the farmers stated that both the farmer and buyer negotiated to set the price.

Notably, the correlation analysis between the price received by farmers (Pcf) and selected marketing factors showed that Pcf was negatively associated with who sets the price. This indicates that Pcf is higher (PhP17.97/kg) when both the farmer and the buyer negotiate for the price and Pcf is lower (PhP17.37/kg) when only the buyer sets the price. Farmers can negotiate especially when they have the volume of copra. For example, a farmer with a volume of $10 \mathrm{t}$ of copra can negotiate for a price higher by $\mathrm{P} 0.50-0.80 / \mathrm{kg}$ than the "on-the-spot" price. 
Traders or dealers had several options or strategies to increase income. Since traders had the volume, $67 \%$ of the traders surveyed availed themselves of a premium price based on negotiated contracts in selling. Additional income of about $\mathrm{PhP} 0.20 / \mathrm{kg}$ to $\mathrm{PhP} 0.70 / \mathrm{kg}$ was noted depending on the volume of copra contracted. Traders also availed themselves of negotiated contracts to serve as their protection for any price fluctuations. When spot price was on a downward trend, traders rushed in to contracts. When traders were under contract and the copra price was going up, they either fulfilled their existing contracts as soon as possible then availed of the higher spot price or they made partial delivery of the volume contracted and traded the rest of the volume under spot price. A premium price was also given during copra shortage or when mills had to fulfill a commitment. Hence, the price received by traders depended on the volume, loyalty, competition in the area, and the timing of the sale. About $39 \%$ of the traders also mentioned that they applied the cost plus profit method in determining the buying price. Hence, prices received by farmers net of Pasa discounts and freight costs were much lower.

The marketing strategies of millers involved positioning of inventory or making a forward sale. Cost management was also a priority and this allowed them to be price competitive. In buying, price determination methods included costs + profit (14.29\%), negotiation/contract $(28.6 \%)$, and spot price $(28.57 \%)$.

\section{Conclusion}

The mill-dealer copra markets are more integrated, albeit weak and showing long-run integration, than the mill-farmer and dealerfarmer copra markets, which showed no integration at all. The degree of integration between market levels was affected by low copra production at the farm level, difference in copra quality being traded, a long chain of intermediaries in the market structure, bottlenecks in transportation and infrastructure facilities, and oligopolistic pricing practices.

\section{Recommendations}

In view of the factors that contributed to the level of market integration, the following are recommended for the improvement of the Philippine copra markets.

\section{Increase Coconut Production/Productivity}

The level of self-sufficiency in production was conspicuous as results of the study pointed to its positive influence to market integration and efficiency. For the flow of price information to be efficient, coconut production should be immensely improved to meet the current and emerging demands in the coconut industry and to facilitate in raising copra farm gate prices. The study highlighted that although mill gate prices in Luzon regions were higher than those in the Mindanao regions, the farm gate prices of the former were lower than the latter. This is because millers involved in interregional procurement of copra imputed the freight cost in their buying price. Since $90 \%$ of the regions are deficit in copra production to meet the demand of millers and processors, helping the coconut regions to be self-sufficient will minimize imports of copra from other regions thus reducing inter-regional transfer cost that the millers had to shoulder to meet their milling requirements. This will also assist to narrow down the mill-farm price differential. Results further showed that improved coconut production was significantly correlated with the type of coconut variety planted and age of palm. Moreover, survey data highlighted that farmers who had planned to cut and convert their coconut plantation had renewed interests in conserving their plantation as they got involved in the production and distribution of new products like virgin coconut oil and coco sap sugar.

Hence, programs to increase coconut production and productivity should be fast tracked and should incorporate areas on 1) planting and replanting of available improved and high-yielding coconut varieties; 2) application at the farm level of appropriate technologies on coconut-based farming systems; and 3) creation of demand and promotion of 
high-value coconut products with farmers as shareholders in the processing of their output.

\section{Increase Investment to Improve Market Infrastructure and Facilities}

The need for improved market infrastructure facilities and specifically farm-tomarket roads was made more evident by the absence of market integration between the coconut farmers and millers/dealers in all regions covered in the study. This area can be tackled with enhanced funding from the Local Government Units (LGUs) and government agencies like the Department of Agriculture (DA), Department of Public Works and Highways (DPWH), and Department of Agrarian Reform (DAR).

\section{Improve Pricing System in Copra Trading}

The study indicated that differences in copra quality as an offshoot of the Pasa approach (system where an automatic deduction in price on copra sale of an amount equal to or greater than $14 \%$ is given without moisture content reading), were a significant factor that led to the absence of market integration at the different market levels. But more glaring was the impact of this on the welfare of the coconut farmers. Price at the miller and dealer level was not efficiently transmitted to the farm level. This means that policies geared towards improving mill copra prices will not have an effect in raising the farm income while the Pasa system is practiced. Hence, the following recommendations are proposed:

Strict implementation and monitoring of copra moisture standards. The mandatory moisture content (MC) reading was generally ignored at the dealer-farmer level during the period of analysis. Moreover, the Pasa system prevailed. The new copra moisture table for copra trading explicitly prohibits the trading of high moisture copra (14\%-18\% MC) and penalizes very low moisture copra arising from prolonged storage. A monitoring scheme by the PCA that would aid in the strict implementation of the new copra pricing system is a must. Otherwise, it is expected that despite the new copra moisture table, farmers will continue to be burdened with a minimum of $14 \%$ discount because copra is generally not rejected by traders and millers, because there is a deficit in copra supply. Employment of neutral operators of moisture meters would also be of immediate benefit to the farmers at the point of sale.

Conduct a stakeholders' forum on copra pricing and quality improvement. It could be emphasized that the objective of getting high profit for the dealers and millers may not be compatible with the objective of providing high income for farmers. Hence, a more participatory approach can be facilitated to provide opportunities for the three groups of stakeholders to settle for a compromise in pricing and income so as to harmonize their incongruent objectives; to discuss solutions on how to correct the Pasa system to give incentives to farmers so that they will continue to survive as producers; and to implement drying technologies like the use of kukum dryer to encourage farmers to produce good copra. The noted aflatoxin problem can be easily solved by good drying, but farmers are dissuaded from delivering good and dried copra because of the Pasa system. Since the weight of copra was a main determinant of income, farmers tended to focus more on weight without fully realizing that deductions due to poor quality can reduce their financial gains. As of now, farmers are disadvantaged by having two systems in operation at the field - the Pasa and resecada system - because anti-competitive dealers take advantage of the lax implementation and subject the farmers to tremendous discounts. With this system uncorrected, price information cannot serve as a guide to policy makers. However, with a uniform standard of copra quality traded, policies geared towards improving the mill copra price will have a positive effect on increasing both the dealers' and farmers' prices. Moreover, the need to adopt improved drying technology at the farm level should go hand in hand with a pricing method that can reward the quality improvement, serving as an incentive for farmers. Related to this, the PCA together with other stakeholders should educate farmers on how to produce good quality copra as well as 
how to come up with acceptable but more equitable strategies in processing and pricing.

Strengthen Existing Coconut Farmers Organizations. One of the major observations of the study was that size, structure, and opportunities available to the key players had a significant bearing on the integration and price efficiency of the markets in the coconut industry. It was noted that small coconut farmers comprised about $89 \%$ of the coconut stakeholders but they got a miserly $25 \%$ of the potential income from coconut between the farm and the export market. On the other hand, the traders and processors who made up only $2.5 \%$ of the industry got $26 \%$ of the income while the large coconut farm owners which comprise only $8.5 \%$ of the industry get $49 \%$ of the income (CIIF and in Aragon, 2002).

Coconut production and trading in the Philippines has been considered to be unsuitable for industrial use because of the inefficiency of having to deal with thousands of small holders and several layers of domestic traders. Despite this inefficiency, exporters still derive multimillion peso profits. Coconut exporters belong to the top 500 corporations in the Philippines. This can be attributed to the continued efforts of the milling sector and exporters to address areas of inefficiency. However, some innovative strategies can be implemented so that a more equitable benefit could flow down to the farmers. In any proposed developments, farmers should be factored in as partners in production and processing and not just providers of raw materials. Their active involvement would greatly distribute benefits and improve the welfare of farmers. Otherwise there will be a more skewed farm structure to the peril of small farmers.

The survey revealed that dealers and millers employed several options or strategies to increase income. At the farm level, the coconut farmer organizations can be an effective vehicle to increase the income of farmers, if properly managed. Some marketing strategies that can be adopted by the farmers' organizations include serving as "co-producer of oil" in toll crushing agreements. This is an opportunity for farmers to increase their incomes since they do not need to be concerned with the volatile price of copra but they can sell a more valuable product - the coconut oil. However, crucial to any change is the efficiency and effective implementation so that benefits will be legitimately and equitably shared. Although results of this study indicated that there was an improvement in the price efficiency since competitive FOB pricing characterized salient marketing points, anticompetitive practices in the marketing of coconut also existed such that benefits did not accrue to the farmers but went to some unscrupulous traders. Hence, the government should not only aggressively implement programs for farmers and the coconut industry but more importantly, it should be morally vigilant in ensuring that checkpoints be in place to discourage anti-competitive practices.

\section{Acknowledgement}

The authors wish to express their gratitude to: The Department of AgricultureBureau of Agricultural Research (DA-BAR), UPLB Foundation, Inc, Philippine Coconut Authority (PCA), PCA-RDEB, PCA-FOB, and PCA-ZRC for the financial and administrative assistance; PCA-Trade and Market Development Branch, Bureau of Agricultural Statistics (BAS), United Coconut Associations of the Philippines (UCAP) for the secondary data; The PCA Regional and Provincial Managers and staff for the great help during the conduct of the survey; Dr. Felino P. Lansigan; Dr. Corazon T. Aragon, Dr. Zenaida M. Sumalde, Dr. Mario V. Perilla for the vital inputs in the analysis and improvement of the paper; Mr. Ramon L. Rivera and the PCA-ZRC BGD staff for the valuable support throughout the conduct of the study.

\section{References}

Aragon, C.T., et al. 2002. Investment Policy Framework and Indicative Investment Plan for Coconut RDE (2001-2020). Prepared for the Coconut RDE Network by CEM, UPLB, FSSRI-CA, UPLB, CEAT, UPLB, PCARRD-DOST and Philippine Coconut Authority, April 2002. 
De Los Reyes, J. 1994. The Dynamics of Feed Corn Price Formation in the Philippines: A Market Integration Approach. Unpublished M.S. Thesis, University of the Philippines at Los Baños.

Faminow, M.D. and B.L. Benson. 1990. Integration of Spatial Markets. Amer. J. Agr. Econ 72:49-62.

Kesavan, T., S.V. Aradhyula, and S.R. Johnson. 1992. Dynamics and Price Volatility in Farm-Retail Livestock Price Relationships. Journal of Agricultural and Resource Economics, 17(2):348-361

Manuel, P.C. and M.V. Maunahan. 1982. Coconut/Copra Marketing System - Its Structure, Conduct and Performance. Terminal report, Department of Agric'l
Econ, CDEM, UP Los Baños, College, Laguna.

Peña de la, S. 1997. Copra and Coconut Oil Trading - Philippine Perspective. Coconuts Today, November 1997: 31-40.

Sinharoy, S. and S.R. Nair. 1994. International Trade and Pepper Price Variations: A Cointegration Approach. Indian Journal of Agricultural Economics, 49(3):417425.

Tibayan, Alice. 1983. Market Structure, Conduct and Performance of Copra Marketing System in Selected Towns of Bicol Region. M.S. Thesis, University of the Philippines Los Baños, College, Laguna. 